\title{
Tentative key to robber fly (Diptera: Asilidae) subfamilies based on pupal cases
}

\author{
D. STEVE DENNIS ${ }^{1,3} \&$ JEFFREY K. BARNES ${ }^{2}$ \\ ${ }^{1} 1105$ Myrtle Wood Drive, St. Augustine, FL 32086-4838, USA.E-mail: dstevedennis@msn.com \\ ${ }^{2}$ Department of Entomology, University of Arkansas, 319 Agriculture Building, Fayetteville, AR 72701, USA. \\ E-mail: jbarnes@uark.edu \\ ${ }^{3}$ Corresponding author
}

\begin{abstract}
Subfamily keys for pupal cases of Asilidae are currently based on 5 taxa, Asilinae, Dasypogoninae, Megapodinae, Laphriinae and Leptogastrinae. Analysis of recently published adult morphological data and DNA sequence data suggests that the family consists of 14 subfamilies. A tentative key based on known pupal cases is provided for 10 of these subfamilies: Asilinae, Brachyrhopalinae, Dasypogoninae, Dioctriinae, Laphriinae, Leptogastrinae, Ommatiinae, Stenopogoninae, Stichopogoninae and Willistonininae. It is difficult to distinguish between Brachyrhopalinae and Dasypogoninae pupal cases because so many characteristics overlap. There are no described pupal cases for 4 subfamilies: Bathypogoninae, Phellinae, Tillobromatinae and Trigonomiminae. Morphological data are available for only approximately $10 \%$ of the genera and $2 \%$ of the species of Asilidae.
\end{abstract}

Key words: Immature Diptera, Insecta, Brachycera, Asiloidea, Asilidae, robber fly, pupal cases, subfamily key

\section{Introduction}

According to Dikow (2003), Latreille (1802) established the family Asilidae in 1802. Since then the subfamily classification has changed considerably with the addition of new subfamilies and with tribes being elevated to subfamily status based primarily on morphological data. From the late 1830s through the mid 1960s, various authors subdivided the family into 2-5 subfamilies. In the early 1970s, Papavero (1973) proposed eight subfamilies: Apocleinae, Asilinae, Dasypogoninae, Laphriinae, Laphystiinae, Ommatiinae, Stenopogoninae, and Trigonomiminae. Depending on the taxonomist, up to an additional four subfamilies were added by the early 2000s: Atomosinae, Dioctriinae, Megapodinae and Stichopogoninae (Artigas \& Papavero 1988; Bybee et al. 2004; Dikow \& GellerGrimm 2004; Geller-Grimm 2003, 2004; Lehr 1969, 1977, 1996).

Bybee et al. (2004) presented the first formal analysis of molecular evidence for phylogenetic relationships among the Asilidae and recognized 10 subfamilies: Apocleinae, Asilinae, Dasypogoninae, Laphriinae, Laphystiinae, Leptogastrinae, Ommatiinae, Stenopogoninae, Stichopogoninae and Trigonomiminae. Most recently Dikow (2009a, b) used both morphological and DNA sequence data to recognize 14 subfamilies: Asilinae, Bathypogoninae, Brachyrhopalinae, Dasypogoninae, Dioctriinae, Laphriinae, Leptogastrinae, Ommatiinae, Phellinae, Stenopogoninae, Stichopogoninae, Tillobromatiinae, Trigonomiminae and Willistonininae.

Because of the lack of detailed descriptions of asilid pupal cases, subfamily classification based on pupal cases has not kept up with that based on adults. Dennis et al. (2008a) commented that, for at least Nearctic pupal cases, a subfamily and subfamily-group classification was most useful. They used the subfamilies Laphriinae and Leptogastrinae and the groups Asilinae-group and Dasypogoninae-group.

In the present study, we evaluate known Asilidae pupal cases to develop a tentative key based on Dikow's (2009a, b) 14 subfamilies. 


\section{Materials and Methods}

Specimens described in Dennis and Knutson (1988), Dennis and Lavigne (1976), and Dennis et al. (2008a, b), and other morphological literature were used to develop the tentative subfamily key. The information in the literature used here includes written descriptions, drawings and photographs evaluated as shown in Table 1. We tested the key using real pupal cases.

TABLE 1. References used to develop the tentative key for Asilidae subfamilies based on pupal cases.

\begin{tabular}{|c|c|}
\hline SUBFAMILY/GENUS/SPECIES & REFERENCE \\
\hline \multicolumn{2}{|l|}{ ASILINAE } \\
\hline Alcimus rubiginosus Gerstaecker, 1871 & Engel \& Cuthbertson (1934) \\
\hline Aneomochtherus perplexus (Becker, 1923) & Zinov'eva (1959, as Neomochtherus) \\
\hline Antipalus varipes (Meigen, 1820) & Musso (1978) \\
\hline Asilus barbarus Linnaeus, 1758 & Séguy (1927) \\
\hline Asilus sericeus Say, 1823 & Bromley (1946), Dennis et al. (2008a), Malloch $(1915,1917)$ \\
\hline Blepharotes coriarius (Wiedemann, 1830) & Weber \& Lavigne (2004) \\
\hline Colepia ingloria (MacLeay, 1827) & Daniels (1987) \\
\hline Colepia malleola (Walker, 1849) & Daniels (1987) \\
\hline Colepia rufiventris (Macquart, 1838) & Daniels (1987) \\
\hline Didysmachus picipes (Meigen, 1820) & Melin (1923, as Dysmachus forcipula Zeller,1840) \\
\hline Dysmachus hamulatus (Loew, 1854) & Musso (1978) \\
\hline Dysmachus trigonus (Meigen, 1804) & Lundbeck (1908) \\
\hline Dystolmus kiesenwetteri (Loew, 1854) & Musso (1978, as Eutolmus) \\
\hline Echthistus rufinervis (Meigen, 1820) & Zinov'eva (1959) \\
\hline Efferia aestuans (Linnaeus, 1763) & $\begin{array}{l}\text { Bromley (1946, as Erax); Dennis et al. (2008a), Malloch (1917, as } \\
\text { Erax) }\end{array}$ \\
\hline Efferia benedicti (Bromley, 1940) & Dennis et al. (2008a), Dennis \& Lavigne (1976) \\
\hline Efferia frewingi Wilcox, 1966 & Dennis et al. (2008a), Dennis \& Lavigne (1976) \\
\hline Efferia helenae (Bromley, 1951) & Dennis et al. (2008a), Dennis \& Lavigne (1976) \\
\hline Efferia maculatus Scopoli, 1763 & Malloch (1917) \\
\hline Efferia triton (Osten Sacken, 1887) & Dennis et al. (2008a) \\
\hline Eutolmus rufibarbis (Meigen, 1820) & Esipenko (1967) \\
\hline Gibbasilus arenaceus Londt, 1986 & Londt (1986) \\
\hline Machimus annulipes (Brullé, 1832) & Kurkina (1979) \\
\hline Machimus atricapillus (Fallén, 1814) & $\begin{array}{l}\text { Melin (1923), Séguy (1927), } \\
\text { Zinov'eva (1959) }\end{array}$ \\
\hline Machimus erythocnemius (Hine, 1909) & Dennis et al. (2008a), Scarbrough \& Kuhar (1995) \\
\hline Machimus fimbriatus (Meigen, 1804) & Séguy (1927) \\
\hline Machimus gonatistes (Zeller, 1840) & Zinov’eva (1959) \\
\hline Machimus lecythus (Walker, 1849) & Dennis et al. (2008a) \\
\hline Machimus notatus (Wiedemann, 1828) & $\begin{array}{l}\text { Bromley (1946, as Asilus), Dennis et al. (2008a), Malloch (1915, } \\
1917 \text { as Asilus) }\end{array}$ \\
\hline Machimus occidentalis (Hine, 1909) & $\begin{array}{l}\text { Dennis et al. (2008a), Dennis \& Lavigne (1976, as Machimus sp. } \\
\text { either callidus (Williston, 1893) or occidentalis (Hine, 1909)) }\end{array}$ \\
\hline Machimus paropus (Walker, 1849) & Dennis et al. (2008a), Scarbrough \& Kuhar (1995) \\
\hline Machimus pilipes (Meigen, 1820) & Musso (1978) \\
\hline
\end{tabular}


TABLE 1. (continued)

\begin{tabular}{|c|c|}
\hline SUBFAMILY/GENUS/SPECIES & REFERENCE \\
\hline Machimus rusticus (Meigen, 1820) & Musso (1978) \\
\hline Machimus snowii (Hine, 1909) & Dennis et al. (2008a), Scarbrough \& Kuhar (1995) \\
\hline Machimus sp., Loew, 1849 & Séguy (1927) \\
\hline Mallophora atra Macquart, 1834 & Dennis et al. (2008b) \\
\hline Mallophora bomboides (Wiedemann, 1828) & Dennis et al. (2008a) \\
\hline Mallophora fautrix Ostern Sacken, 1887 & Dennis et al. (2008a) \\
\hline Mallophora leschenaultii Macquart, 1838 & Dennis et al. (2008a) \\
\hline Mallophora orcina (Wiedemann, 1828) & Dennis et al. (2008a) \\
\hline Mallophora ruficauda (Wiedemann, 1828) & Dennis \& Knutson (1988), Copello $(1927,1942)$ \\
\hline Mallophora sylveirii Macquart, 1838 & Dennis \& Knutson (1988) \\
\hline Megaphorus guildiana (Hine, 1885) & Dennis et al. (2008a), Dennis \& Lavigne (1976, as Mallophorina) \\
\hline Neoepitriptus setosulus (Zeller, 1840) & Musso (1978, as Eptriptus) \\
\hline Neoitamus cyanurus (Loew, 1849) & Lundbeck (1908), Melin (1923) \\
\hline Neoitamus socius (Loew, 1871) & Melin (1923) \\
\hline Neomochtherus angustipennis (Hine, 1909) & Knutson (1972) \\
\hline Neomochtherus aquitanus Tsacas, 1964 & Musso (1978) \\
\hline Neomochtherus geniculatus (Meigen, 1820) & Brauns (1954, as Cerdistus) \\
\hline Pamponerus germanicus (Linnaeus, 1758) & Melin (1923), Séguy (1927) \\
\hline Philonicus albiceps (Meigen, 1820) & Brauns (1954), Melin (1923), Séguy (1927) \\
\hline Promachus bastardii (Macquart, 1838) & Dennis et al. (2008a) \\
\hline Promachus vertebratus (Say, 1823) & Davis (1919), Dennis et al. (2008a), Malloch $(1915,1916,1917)$ \\
\hline Proctacanthella cacopiloga (Hine, 1909) & Dennis et al. (2008), Dennis \& Lavigne (1976) \\
\hline Proctacanthus hinei Bromley, 1928 & Dennis et al. (2008a) \\
\hline Proctacanthus micans Schiner, 1867 & Dennis et al. (2008a), Dennis \& Lavigne (1976) \\
\hline Proctacanthus milbertii Macquart, 1838 & Dennis et al. (2008a), Malloch $(1915,1917)$ \\
\hline Proctacanthus philadelphicus Macquart, 1838 & Bromley (1946), Dennis et al. (2008a), Malloch (1917) \\
\hline Proctacanthus rufus Williston, 1885 & Dennis et al. (2008a) \\
\hline Rhadiurgus variabilis (Zetterstedt, 1838) & Melin (1923) \\
\hline Satanas gigas (Eversmann, 1855) & Zinov’eva (1959) \\
\hline Tolmerus cingulatus (Fabricius, 1781) & Melin (1923) \\
\hline Triorla interrupta (Macquart, 1834) & Dennis et al. (2008a) \\
\hline Triorla striola (Fabricius, 1805) & Dennis \& Knutson (1988) \\
\hline Zosteria fulvipubescens (Macquart, 1850) & Daniels (1987) \\
\hline Zosteria sydneensis (Macquart, 1838) & Daniels (1987) \\
\hline
\end{tabular}

\section{BRACHYRHOPALINAE}

Ceraturgus cruciatus (Say, 1823)

Ceraturgus fasciatus Walker, 1847

Chrysopogon sp. near fasciatus Ricardo, 1912

Cyrtopogon lateralis (Fallén, 1814)

Heteropogon macerinus (Walker, 1849)

Heteropogon wilcoxi James, 1934

Bromley (1946), Malloch (1917)

Dennis et al. (2008a)

Lavigne, R.J. (pers. comm., drawing in S.J. Paramonov file at Australian National Insect Collection in Canberra, Australia)

Melin (1923), Séguy (1927)

Dennis et al. (2008a)

Dennis et al. (2008a), Dennis \& Lavigne (1976) 
TABLE 1. (continued)

\begin{tabular}{ll}
\hline SUBFAMILY/GENUS/SPECIES & REFERENCE \\
\hline Holopogon venustus (Rossi, 1790) & Musso (1978) \\
Leptarthus brevirostris (Meigen, 1804) & Parmenter (1952, as Isopogon)
\end{tabular}

\section{DASYPOGONINAE}

Comantella fallei (Back, 1909)

Dennis et al. (2008a), Dennis \& Lavigne (1976)

Dasypogon diadema (Fabricius, 1781)

Musso (1978)

Diogmites discolor Loew, 1866

Bromley (1946), Malloch (1917, as Deromyia)

Diogmites misellus Loew, 1866

Diogmites neoternatus (Bromley, 1931)

Diogmites winthemi (Wiedemann, 1921)

Diogmites vulgaris Carrera, 1947

Pseudoras distendens (Wiedemann, 1828)

Bromley (1946), Dennis et al. (2008a)

Dennis et al. (2008a)

Malloch (1915, 1917, as Deromyia; per Dennis \& Knutson (1988), adult specimens appear to be Diogmites misellus Loew, 1866 and not D. winthemi)

Dennis \& Knutson (1988)

Knutson (1976, as Doryclus)

\section{DIOCTRIINAE}

Dioctria atricapilla Meigen, 1804

Melin (1923)

Dioctria bicincta Meigen, 1820

Dioctria hyalipennis (Fabricius, 1794)

Musso (1978)

Brauns (1954), Melin (1923), Séguy (1927)

Dioctria rufipes (DeGeer, 1776)

Brindle (1968)

Dioctria sp. Meigen, 1803

Lundbeck (1908)

\section{LAPHRIINAE}

Andrenosoma atrum (Linnaeus, 1758)

Brauer (1883), Dufour (1850, as Laphria atra Fabricius, 1805), Musso (1967, 1978), Perris (1870, as Laphria atra Fabricius, 1805)

Andrenosoma bayardi Seguy, 1952

Andrenosoma albopilosum Villeneuve, 1911

Choerades caucasicus Richter \& Mamajev, 1971

Musso $(1967,1978)$

Oldroyd (1939)

Richter \& Mamajev (1971)

Choerades fulva (Meigen, 1804)

Brauns (1954, as Epholkiolaphria)

Choerades gilva (Linnaeus, 1758)

Brauns (1954, as Epholkiolaphria), Lundbeck (1908), Melin (1923), Perris (1870), Séguy, (1927) (all as Laphria)

Choerades ignea Meigen, 1820

Choerades marginata (Linnaeus, 1758)

Hyperechia bifasciata Grünberg, 1907

Melin (1923, as Laphria)

Hennig (1952), Melin (1923) (both as Laphria)

Thorpe (1927)

Hyperechia bomboides (Loew, 1851)

Tsacas et al. (1970)

Thorpe (1927)

Hyperechia consimilis (Wood, 1874)

Engel \& Cuthbertson (1934)

Hyperechia marshalli Austen, 1902

Hyperechia nigripennis (Wiedemann, 1830)

Engel (1929)

Hyperechia xylocopiformis (Walker, 1849)

Thorpe (1927)

Lampria bicolor (Wiedemann, 1828)

Dennis et al. (2008a)

Laphria aimatis McAtee, 1919

Dennis et al. (2008a)

Laphria ephippium (Fabricius, 1781)

Melin (1923)

Laphria flava (Linnaeus, 1761)

Melin (1923) 
TABLE 1. (continued)

\begin{tabular}{ll}
\hline SUBFAMILY/GENUS/SPECIES & REFERENCE \\
\hline Laphria flavicollis Say, 1824 & Dennis et al. (2008a) \\
Laphria gibbosa (Linnaeus, 1758) & Melin (1923), Séguy (1927) \\
Laphria index McAtee, 1919 & Bullington (1986), Dennis et al. (2008a) \\
Laphria rapax Osten Sacken, 1877 & Bullington (1986) \\
Laphria sackeni (Banks, 1917) & Dennis et al. (2008a) \\
Laphria sericea Say, 1823 & Bullington (1986), Dennis et al. (2008a) \\
Laphria thoracica Fabricius, 1805 & Bromley (1946), Dennis et al. (2008a), Greene (1917, as Dasyllis) \\
Laphystia carnea Hermann, 1906 & Krivosheina (1973) \\
Pogonosoma maroccanum (Fabricius, 1794) & Séguy, 1927 \\
Proagonistes austeni Bromley, 1930 & Engel (1932)
\end{tabular}

\section{LEPTOGASTRINAE}

Apachekolas tenuipes (Loew, 1862)

Leptogaster cylindrica (DeGeer, 1776)

Dennis et al. (2008a)

Brauns (1954), Esipenko (1973), Melin (1923), Séguy (1927), Zinov'eva (1959)

Leptogaster flavipes Loew, 1862

Bromley (1946), Dennis et al. (2008a), Malloch (1917)

Leptogaster guttiventris Zetterstedt, 1842

Melin (1923)

\section{OMMATIINAE}

Ommatius gemma Brimley, 1928

Dennis et al. (2008a)

Ommatius orenoquensis Bigot, 1876

Cezar \& Lamas (2010)

Ommatius tibialis Say, 1823

Dennis et al. (2008a)

\section{STENOPOGONINAE}

Stenopogon inquinatus Loew, 1866

Dennis et al. (2008a); Dennis \& Lavigne (1976)

Stenopogon rufibarbis Bromley, 1931

Dennis et al. (2008a)

\section{STICHOPOGONINAE}

Lasiopogon cinctus (Fabricius, 1781)

Lundbeck (1908), Melin (1923), Séguy (1927)

\section{WILLISTONININAE}

Willistonina bilineata (Williston, 1883)

Wilcox (1935)

Terminology for pupal case morphology follows that of Dennis et al. (2008a, b). This terminology is labeled on Figs. 1-3 for Lampria bicolor (Wiedemann, 1828). The pupal case of this species was selected because it shows most of the morphological features of asilid pupal cases.

The head, thorax and abdomen are easily distinguished. The head, with its ventral mouthpart sheaths and lateral eye sheaths, is separated from the thorax by a cephalothoracic suture (ctst) that passes just above the prothoracic spiracle (pthsr). It generally bears terminal anterior antennal processes (aap) that are curved ventrally. Each eye sheath has a posterior antennal process (pap) consisting of 3-6 basally fused hooks. The head ventrally has frontal sutures (fst) between the posterior antennal processes. In the Laphriinae, as shown on Fig. 1, the lower part of the facial area has median facial spines ( $\mathrm{mfsp}$ ) or lateral facial spines (lfsp). In the tribe Megapodini, there are ventral suborbital spines on each side of the head, anterior to the bases of the anterior coxal sheaths (acsh).

On the posterior part of the facial area are the mouthpart sheaths (Fig. 1). The labral sheath (lsh) is located medially and on either side are the maxillary sheaths (msh). The proboscial sheath (prsh) is located posterior to the labral sheath. On some pupal cases, a pair of small callosities is visible on either side of the labral sheath. Dennis et al. (2008a) indicated that these callosities apparently represent palpal sheaths. 
The paired anterior coxal sheaths (acsh) are lateral to the maxillary sheaths. At the base of the anterior coxal sheaths is the posterior coxal sheath (pcsh), which usually covers the coxae of the hind legs. The fore leg sheaths (lesh 1) are on both sides of the anterior coxal sheaths. The second or mid (lesh 2) and third or hind (lesh 3) leg sheaths are lateral to the fore leg sheaths. The hind leg sheaths are mostly hidden by the wing sheaths (wsh), although their apices project beyond or posterior to the wing sheaths.

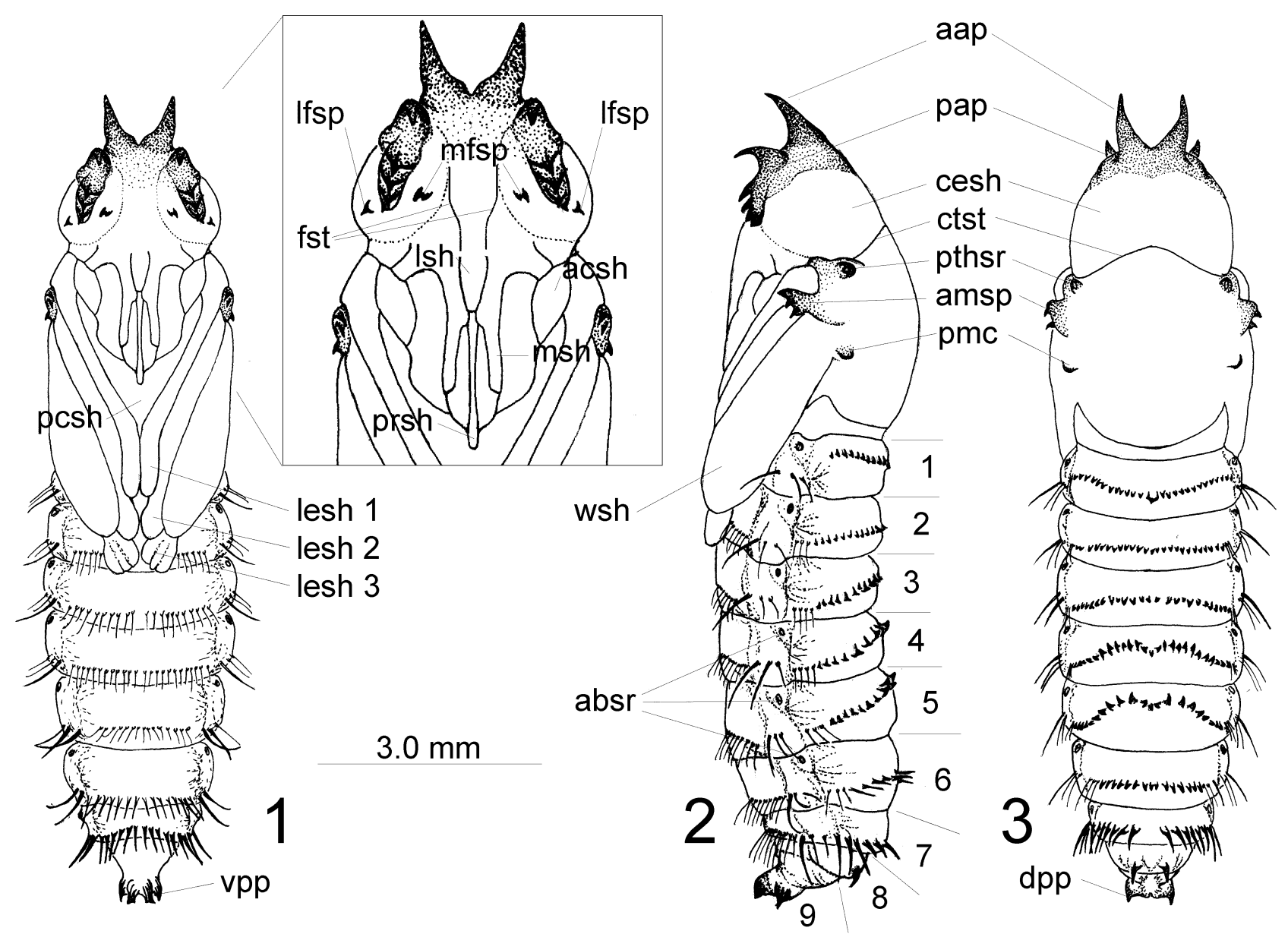

FIGURES 1-3. Lampria bicolor pupal case. 1, ventral view with enlargement of facial area; 2, lateral view with abdominal segments numbered; 3, dorsal view. Abbreviations: aap = anterior antennal process, absr = abdominal spiracle, acsh $=$ anterior coxal sheath, amsp = anterior mesothoracic spine(s), cesh = compound eye sheath, $\mathrm{ctst}=$ cephalothoracic suture, $\mathrm{dpp}=\mathrm{dorsal}$ posterolateral process, $\mathrm{fst}=$ frontal suture, lesh $1=$ fore leg sheath, lesh $2=$ mid leg sheath, lesh $3=$ hind leg sheath, lfsp $=$ lateral facial spine, $1 \mathrm{sh}=$ labral sheath, $\mathrm{mfsp}=$ median facial spine, $\mathrm{msh}=$ maxillary sheath, $\mathrm{pap}=$ posterior antennal process, $\mathrm{pcsh}$ $=$ posterior coxal sheath, $\mathrm{pmc}=$ posterior mesothoracic callosity, $\mathrm{prsh}=$ proboscial sheath, $\mathrm{pthsr}=$ prothoracic spiracle, $\mathrm{vpp}=$ ventral posterolateral process, wsh $=$ wing sheath $($ after Dennis et al. $2008 \mathrm{a})$.

The prothoracic spiracles (pthsr) are located on each side of the thorax at the anterior margin (Fig. 2). A pair of anterior mesothoracic spines (amsp) is usually located on each side of the thorax at the base of the mid leg sheaths or there may be a sclerotized edge on a callosity. A posterior mesothoracic spine is also usually located on a posterior mesothoracic callosity (pmc) at the base of each wing sheath.

As discussed in Dennis et al. (2008a, b), we recognize nine abdominal segments and abdominal processes consisting of spines and spurs as defined by Comstock (1925) and Daly et al. (1998). A spine is a rigid, immovable, thorn-like outgrowth of the cuticle that is not separated from it by a joint. It does not have a socket area of integumental weakness around its base. A spur is a moveable process of the cuticle that is connected to the body wall by a joint, and has a socket or integumental weakness or constriction around its base. Some spines also might be bristle-like, but a bristle is defined as an unicellular macrotrichium or seta connected with nerves and surrounded at the base by a membranous ring or socket called an alveolus (Daly et al. 1998; McAlpine 1981). 
Typically abdominal segment 1 has a dorsal transverse row of spurs, and segments 2-7 have a dorsal transverse row of long spines alternating with short spurs. However, the known described pupal cases of species of Laphriinae lack discernible spurs (Dennis et al. 2008a) (Fig. 3). There are dorsolateral, lateral (posterior to the abdominal spiracles), and ventral bristle-like spines. Each of the first 7 abdominal segments has lateral abdominal spiracles (absr).

Abdominal segment 8 has a distinctive arrangement of dorsal, dorsolateral, lateral, and ventral spurs and spines (Figs. 1-3). Depending on the species, one or more of these groups might be absent. On some species the spiracles can be seen on segment 8 , but they are often located more dorsally than on the other abdominal segments.

Abdominal segment 9 has a combination of dorsal posterolateral processes (dpp), ventral posterolateral processes (vpp) and ventromedial processes, and sometimes a distinct arrangement of tubercles or callosities. Male pupal cases can often be distinguished from female cases by a pair of enlarged midventral callosities.

\section{Results and discussion}

Up until Knutson (1972) described the pupa of Neomochtherus angustipennis (Hine, 1909), the majority of written descriptions of asilid pupal cases were not detailed enough for pupal case identification and did not follow a standard format. As a result, our research also relies on drawings and photographs to distinguish among pupal cases.

We developed the following tentative key to 10 of the 14 subfamilies based on the references shown in Table 1 . Most information is available for the subfamilies Asilinae (29 genera and 66 species) and Laphriinae ( 7 genera and 28 species). Less is available for the Brachyrhopalinae (6 genera and 8 species), Dasypogoninae (4 genera and 8 species), Leptogastrinae ( 2 genera and 4 species), Dioctriinae ( 1 genus and 4 species), Ommatiinae (1 genus and 3 species), Stenopogoninae (1 genus and 2 species), and Stichopogoninae and Willistonininae (1 genus and 1 species each). Some pupal case descriptive information is based on genera and species previously placed in the Apocleinae + Asilinae, Laphriinae + Laphystiinae, and Leptogastrinae, that have not been formally placed in a subfamily taxon based on morphology and DNA sequence data. However, Dikow (2009a) indicates that they can still be placed in Asilinae, Laphriinae and Leptogastrinae, and so they are included in Table 1. Out of the 530 valid genera and 7003 species of Asilidae (Geller-Grimm 2011), there is published information on the pupal cases of only 53 genera $(10.0 \%)$ and 125 species $(1.8 \%)$ that can help identify pupal cases.

The pupal cases of most subfamilies can be distinguished from each other based on major characteristics, such as the presence or absence of anterior and posterior mesothoracic spines. However, based on available information for the Brachyrhopalinae and Dasypogoninae, it is difficult to tell the difference between their pupal cases.

The limited information for most subfamilies and the lack of information for four of the subfamilies emphasizes the need for more detailed pupal case descriptions. Information is not available for genera and/or species in the subfamilies Bathypogoninae, Phellinae, Tillobromatinae and Trigonomiminae, although these subfamilies are part of the Dasypogoninae group and they would be expected to be included in the subfamily key below (couplets 5 through 8 ).

The lack of pupal case information for these four subfamilies is probably due to their limited world distributions compared to other subfamilies. According to Dikow (2009b), the Trigonomiminae have a worldwide distribution, the Bathypogoninae are restricted to Australia and possibly South America, the Phellinae occur only in Australia and Chile, and the Tillobromatinae are found in southern Africa and South America.

\section{Tentative key to Asilidae subfamilies based on known pupal cases}

Anterior antennal processes dorsoventrally flattened and joined at base or tuberculate and poorly developed; posterior antennal processes palmate or represented by only a ridged callosity; dorsum of thorax with 4 bristle-like structures forming corners of a square or rectangle; abdominal segments dorsally with anterior row of short spines and posterior row of hair-like processes longer than the length of each segment; abdominal segments laterally and ventrally with hair-like processes longer than the length of each segment; abdominal segment 9 with 1 pair of terminal processes $\ldots \ldots \ldots \ldots \ldots \ldots \ldots$. Leptogastrinae Anterior antennal processes long, acuminate; posterior antennal process consisting of 3-6 basally fused, horn-like, hook-like or elongate antler-like processes; dorsum of thorax with 0,2 or 4 bristle-like structures; abdominal segments dorsally with spines and/or spurs, lacking long bristle-like or hair-like processes; abdominal segments laterally and ventrally with spines shorter than length of each segment; abdominal segment 9 with $2-6$ pairs of terminal processes. . . . . . . . . . . . Abdominal segments 1-7 lacking discernable dorsal spurs; lower facial area with median or lateral spines; posterior antennal 
processes consisting of 3-6 confluent hooks that are sometimes elongate and antler-like with alternating long and short hooks; abdominal segment 9 with or without ventral posterolateral processes larger and/or broader than dorsal posterolateral processes

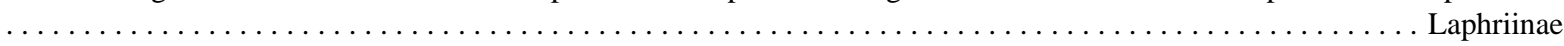
Abdominal segment 1 with dorsal transverse row of long spurs; segments 2-7 with or without dorsal row of long spurs alternating with short spines; lower facial area without median or lateral spines; posterior antennal processes usually consisting of only 3 confluent hooks but if $4-6$, then hooks short to long and narrow; abdominal segment 9 with ventral posterolateral pro-

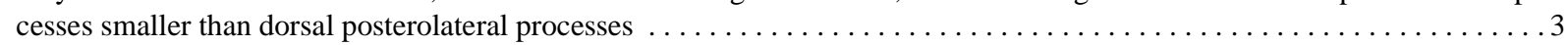
Head with posterior antennal processes consisting of 3-6 hooks; abdominal segment 9 with dorsal posterolateral and ventral posterolateral processes curved dorsally, the ventral ones curved toward dorsal ones, or processes straight to curved dorsally;

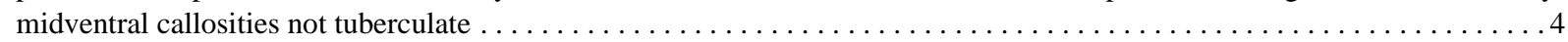
Head with posterior antennal processes consisting of 3 hooks; abdominal segment 9 with dorsal posterolateral processes curved or pointed dorsally and ventral posterolateral processes generally pointed ventrally or in opposite direction of dorsal ones; midventral callosities, when present, usually tuberculate with sclerotized tip $\ldots \ldots \ldots \ldots \ldots \ldots \ldots$ Abdominal segments lacking alternately long spurs and short spines dorsally; some abdominal segments, in particular anterior ones, sometimes with short medial spines; abdominal segments lacking ventral bristle-like spines; anterior and posterior meso-

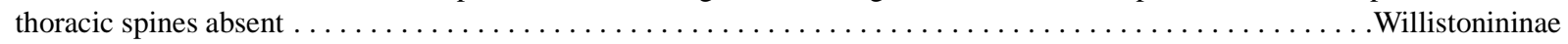
Some abdominal segments, in particular anterior ones, with alternately long spurs and short spines dorsally; abdominal segments with or without short, medial spines; some abdominal segments with or without ventral bristle-like spines; anterior and/

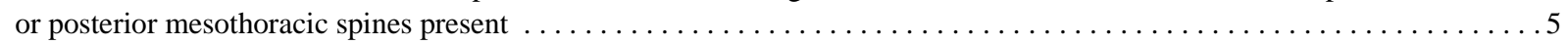
Abdominal segments without ventral bristle-like spines; anterior mesothoracic spines present; posterior mesothoracic spine

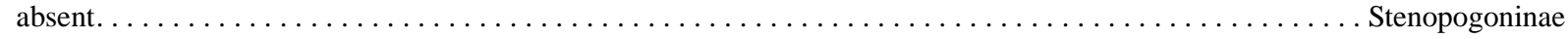
Abdominal segments with or without ventral bristle-like spines; anterior and/or posterior mesothoracic spines present . . . .6

6 Anterior antennal process usually with basal bristle dorsally; thorax with 2 bristles on dorsum; anterior mesothoracic spines absent or callosity with sclerotized edge; posterior mesothoracic callosity with spine or ridge-like with spine; abdominal segment 1 with 8 long spurs dorsally; segments 2-7 with alternating long spurs and short spines dorsally, becoming subequal on

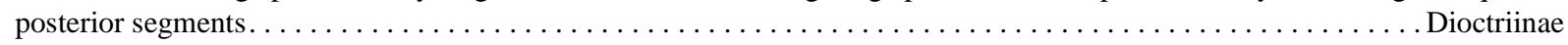
Anterior antennal process with or without basal bristle dorsally; thorax with or without bristles on dorsal surface; anterior mesothoracic spine(s) present; posterior mesothoracic callosity smooth to grooved or rugulose, sometimes with bristle-like spine; abdominal segment 1 with 6-30 (usually 10-16) long spurs dorsally; segments 2-6 with alternating long spurs and short spines dorsally, becoming subequal on posterior segments; segment 7 with or without alternating long spurs and short spines

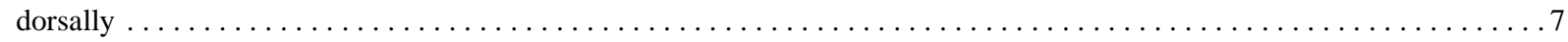
Anterior antennal process without basal bristle dorsally; thorax with bristles on dorsal surface; anterior and posterior mesothoracic spines present; abdominal segments lacking ventral bristle-like spines; abdominal segment 1 with long, dorsal spurs; these spurs apically bent or curved, with saw tooth-like edge $\ldots \ldots \ldots \ldots \ldots \ldots \ldots \ldots \ldots \ldots$ Stichopogoninae Anterior antennal process with or without basal bristle dorsally; thorax with or without bristles on dorsal surface; anterior and/ or posterior mesothoracic spines present and sometimes bristle-like; dorsal spurs of abdominal segment 1 straight to recurved,

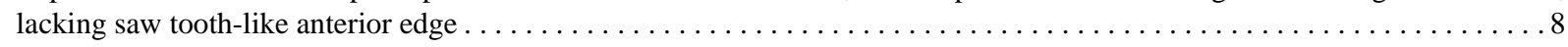
Abdominal segment 1 with 12-30 dorsal spurs; abdominal segments with ventral bristle-like spines; with lateral bristle-like spines posterior to abdominal spiracles; abdominal segment 8 with 4-10 dorsal spurs on each side of midline. Dasypogoninae Abdominal segment 1 with 10-18 dorsal spurs; abdominal segments with or without ventral bristle-like spines; with or without lateral bristle-like spines posterior to abdominal spiracles; abdominal segment 8 with 1-4 dorsal spurs on each side of midline

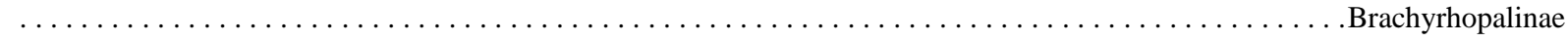
Anterior antennal processes joined basally; anterior and posterior mesothoracic spines absent; posterior mesothoracic callosity

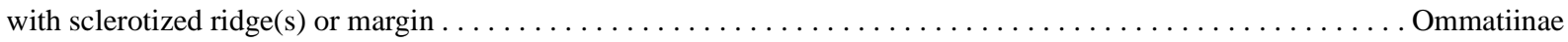
Anterior antennal processes not joined basally; anterior mesothoracic spines absent but with or without posterior mesothoracic spine; posterior mesothoracic callosity smooth to rugose $\ldots \ldots \ldots \ldots \ldots \ldots \ldots \ldots \ldots \ldots \ldots \ldots \ldots \ldots \ldots \ldots \ldots \ldots$

\section{Acknowledgments}

Mary Lou Cooley illustrated the Lampria bicolor pupal case. We thank the anonymous reviewers for their constructive comments.

\section{References}

Artigas, J.N. \& Papavero, N. (1988) The American genera of Asilidae (Diptera): Keys for identification with an atlas of female spermathecae and other morphological details. II. Key to genera of Dasypogoninae Macquart, with description of new genera and species and new synonymies. Gayana Zoologica, 52, 199-260.

Brauer, F. (1883) Die Zweiflügler des Kaiserlichen Museums zu Wien. III. Systematische Studien auf Grundlage der DipterenLarven nebst einer Zusamenstellung von Beispielen aus der Literatur über dieselben und Beschreibung neuer Formen. Denkschriften der Kaiserlichen Akademie der Wissenschaften. Mathematisch-Naturwissenschaftliche Classe, 47, 1-100. 
Brauns, A. (1954) Puppen terricolor Dipterenlarven. Untersuchungen zur Angewandten Bodenbiologie, Band 2. "Musterschmidt" Wissenschaftlicher Verlag, Göttingen, Germany, 156 pp.

Brindle, A. (1968) Taxonomic notes on the larvae of British Diptera, No. 25, The larva and pupa of Dioctria rufipes (DeGeer) (Asilidae). Entomologist, 101, 213-216.

Bromley, S.W. (1946) Guide to insects of Connecticut. Part VI. The Diptera or true flies of Connecticut. Third Fascicle. Asilidae. Bulletin of the Connecticut State Geological and Natural History Survey Bulletin, 69, 1-48.

Bullington, S.W. (1986) Two New Genera Related to Laphria Meigen (Diptera: Asilidae), With Revision of the Included Species in North America North of Mexico. Unpublished Doctoral Dissertation, University of Wyoming, Laramie, Wyoming, $275 \mathrm{pp}$.

Bybee, S.M., Taylor, S.D., Nelson, C.R. \& Whiting, M.F. (2004) A phylogeny of robber flies (Diptera: Asilidae) at the subfamilial level: molecular evidence. Molecular Phylogenetics and Evolution, 30, 789-797.

Cezar, L.A. \& Lamas, C.J.E. (2010) Description of the larva and pupal case of Ommatius orenoquensis Bigot (Diptera,, Asilidae, Ommatiinae). Review Brasileira de Entomologia, 54, 28-31.

Comstock, J.H. (1925) An Introduction to Entomology, second edition. The Comstock Publishing Company, Ithaca, New York, $1044 \mathrm{pp}$.

Copello, A. (1927) Biologia de Moscardón cazador de abejas (Mallophora ruficauda, Wied.). Argentina Ministry of Agriculture (Buenos Aires) Circular 699, 1-19.

Copello, A. (1942) Moscardón cazador de abejas “Mallophora ruficauda." Revista de Apicultura, Argentina, 19(218), 4-5; (219), 10-11; (220), 13-14; (221), 14; (222), 12-13.

Daly, H. V., Doyen, J.T. \& Purcell, A.H. (1998) Introduction to Insect Biology and Diversity, second edition. Oxford University Press, New York, 680 pp.

Daniels, G. (1987) A revision of Neoaratus Ricardo, with the description of six allied new genera from the Australian Region (Diptera: Asilidae: Asilini). Invertebrate Taxonomy, 1, 473-592.

Davis, J.J. (1919) Contributions to a knowledge of the natural enemies of Phyllophaga. Bulletin of the Illinois State Natural History Survey, 13, 53-138.

Dennis, D.S., Barnes, J.K. \& Knutson, L. (2008a) Pupal cases of Nearctic robber flies (Diptera: Asilidae). Zootaxa, 1868, 1-98.

Dennis, D.S., Barnes, J.K. \& Knutson, L. (2008b) The pupal case of Mallophora atra Macquart (Diptera: Asilidae) from South America. Proceedings of the Entomological Society of Washington, 110, 234-241.

Dennis, D.S. \& Knutson, L. (1988) Descriptions of pupae of South American robber flies (Diptera: Asilidae). Annals of the Entomological Society of America, 81, 851-864.

Dennis, D.S. \& Lavigne, R.J. (1976) Descriptions and notes on the pupae and pupal cases of ten species of Wyoming robber flies (Diptera: Asilidae). Proceedings of the Entomological Society of Washington, 78, 277-303.

Dikow, T. (2003) Family-group names in the Asilidae (Diptera). Studia dipterologica, 10, 459-471.

Dikow, T. (2009a) Phylogeny of Asilidae inferred from morphological characteristics of imagines (Insecta: Diptera: Brachycera: Asiloidea). Bulletin of the American Museum of Natural History, 319, 1-175.

Dikow, T, (2009b) A phylogenetic hypothesis for Asilidae based on total evidence analysis of morphological and DNA sequence data (Insecta: Diptera: Brachycera: Asiloidea). Organisms, Diversity \& Evolution, 9, 165-188.

Dikow, T. \& Geller-Grimm, F. (2004) Information on robber fly phylogeny: introduction with a brief history of former studies. Available from:http://www.geller- grimm.de/genera19.htm (accessed 05 March 2011).

Dufour, L. (1850) Recherches pour server a l'historie des métamorphoses des Asiliques. Annales des Science Naturalles, Series 3, Zoology, 13, 141-158.

Engel, E.O. (1929) Notes on two larvae of South African Diptera belonging to the families Leptidae and Asilidae. Transactions of the Royal Society of South Africa, 18, 147-162.

Engel, E.O. (1932) New or little known Asilidae from South Aftrica. II. Annals of the Transvaal Museum, 14, $251-283$.

Engel, E.O. \& Cuthbertson, A. (1934) Systematics and biological notes on some Asilidae (Diptera) of Southern Rhodesia with descriptions of a new species to science. Proceedings of the Rhodesia Scientific Association, 34, 35-47.

Esipenko, P.A. (1967) Biology of the robber fly Eutolmus rufibarbis Mg. (Diptera, Asilidae) in Khabarovsk Territory. Entomological Review, 46, 61-62.

Esipenko, P.A. (1973) The biology of Leptogaster cylindrica DeG. (Diptera, Asilidae) in the Khabarovsk Territory. In : Ivliev, L. A. (Ed.), Entomological Researches in the Far East. Issue. Diptera of the Far East. Trudy-Biologo-poch-vennogo-Instituta, Dal'nevostochnyl-Nauchnyl, Adademiya-Nauk,-SSSR, 5, 130-134.

Geller-Grimm, F. (2003) A world catalogue of the genera of the family Asilidae (Diptera). Studia dipterologica, 10, $473-526$.

Geller-Grimm, F. (2004) Key to the subfamilies of Asilidae (Diptera) after Artigas and Papavero, 1988. Available from: http:// www.geller-grimm.de/subfam.htm (accessed 05 March 2011).

Geller-Grimm, F. (2011) Information on robber flies: Introduction. Available from: http://www.geller-grimm.de/general.htm (accessed 05 March 2011).

Greene, C.T. (1917) A contribution to the biology of North American Diptera. Proceedings of the Entomological Society of Washington, 1, 146-161.

Hennig, W. (1952) Die larvenformen der Dipteren. 3 Teil. Akademie-Verlag, Berlin, 628 pp.

Knutson, L. (1972) Pupa of Neomochtherus angustipenis (Hine), with notes on feeding habits of robber flies and a review of publications on morphology of immature stages (Diptera: Asilidae). Proceedings of the Biological Society of Washington, 
$85,163-178$.

Knutson, L. (1976) Key to subfamilies of robber flies based on pupal cases, with a description of the pupal case of Doryclus distendens (Asilidae: Megapodinae). Proceedings of the Biological Society of Washington, 8, 509-514.

Krivosheina, N.P. (1973) Larvae and pupae of robber flies in the genus Laphystia Lw. (Diptera, Asilidae). Zoologicheskii Zhurnal, 52, 457-459.

Kurkina, L.A. (1979) The biology of Machimus annulipes (Diptera, Asilidae). Entomological Review, 58, $26-30$.

Latreille, P.A. (1802) Histoire Naturelle, Générale et Particulière, des Crustacés et des Insects. Tome troisieme. Paris, 467 pp.

Lehr, P.A. (1969) An ecological and morphological analysis of robber flies (Dipt., Asilidae), Communication II. Entomological Review, 48, 341-357.

Lehr, P.A. (1977) Robber flies from the subfamilies Atomosiinae and Laphriinae (Diptera, Asilidae) from Central Asia and Kazakhstan. Entomological Review, 56, 123-131.

Lehr, P.A. (1996) Robber Fies of Subfamily Asilinae (Diptera, Asilidae) of tbe Palearctic: Ecological and Morphological Analysis, Taxonomy and Evolution. Dalnauka, Vladivostok, 184 pp. (In Russian).

Londt, J.G.H. (1986) Gibbasilus arenaceus, a new genus and species from western Cape Province of South Africa (Diptera: Asilidae: Asilinae). Journal of the Entomological Society of Southern Africa, 49, 1-6.

Lundbeck, W. (1908) Diptera Danica, Genera and Species of Flies Hitherto Found in Denmark. Part II Asilidae, Bombylidae, Therevidae, Scenopinidae. G.E.C. Gad - Copenhagen, 160 pp.

Malloch, J.R. (1915) Some additional records of Chironomidae for Illinois and notes on other Illinois Diptera. Bulletin of the Illinois State Laboratory of Natural History, 11, 305-363.

Malloch, J.R. (1916) A comparison of the pupae of Promachus vertebratus and Promachus fitchii. Bulletin of the Brooklyn Entomological Society, 11, 66-68.

Malloch, J.R. (1917) A preliminary classification of Diptera, exclusive of pupipara, based upon the larval and pupal characters, with keys to imagines in certain families. Part I. Bulletin of the Illinois State Laboratory of Natural History, 12, 161-409.

McAlpine, J.F. (1981) Morphology and terminology - Adults. In: McAlpine, J.F., Peterson, B.V., Shewell, G.E., Teskey, H.J., Vockeroth, J.R. \& Wood, D.M. (Coords). Manual of Nearctic Diptera, volume 1. Research Branch, Agriculture Canada, Monograph, 27, 1-674.

Melin, D. (1923) Contributions to the knowledge of the biology, metamorphosis and distribution of the Swedish asilids in relation to the whole family of asilids. Zoologiska Bidrag frän Uppsala, 8, 1-317.

Musso, J.J. (1967) Etude de la nymphe d'Andrenosoma bayardi Séguy, 1952. (Dipt. Asilidae). Bulletin of de la Société entomologique de France, 72, 75-80.

Musso, J.J. (1978) Recherches sur le Développement, la Nutrition et l'Écologie des Asilidae (Diptera - Brachycera). Doctoral Dissertation, Université de Droit, d'Économie et des Sciences d'Aix-Marseille, 312 pp.

Oldroyd, H. (1939) A note on the pupa of Andrenosoma albopilosum Villn. (Diptera: Asilidae). Proceedings of the Royal Entomological Society of London, Series A, 14, 7-8.

Papavero, N. (1973) Studies of Asilidae (Diptera) systematics and evolution. I. A preliminary classification in subfamilies. Arquivos de Zoologia (São Paulo), 23, 217-274.

Parmenter, L. (1952) The pupa of Isopogon brevirostris Meigen (Diptera, Asilidae). Proceedings of the Royal Entomological Society of London, 27, 43-44.

Perris, E. (1870) Histoire des Insectes du Pin Maritime. Diptères. Annales de la Société Entomologique de France, 10, 135232, 320-366.

Richter, V.A. \& Mamajev, B.M. (1971) New robber-flies of the subfamily Laphriinae (Diptera, Asilidae) in Caucasus. Zoolicheskii Zhurnal, 50, 1589-1591 (in Russian).

Scarbrough, A.G. \& Kuhar, T.P. (1995) Pupal cases of Machimus Loew (Diptera: Asilidae). Maryland Entomologist, 4, 15-22.

Séguy, E. (1927) Faune de France. 17. Diptères (Brachycères) (Asilidae). Fédération Française des Sociétés de Sciences Naturelles, Office Central de Faunnistique, Paris, 190 pp.

Thorpe, W.H. (1927) The larvae and pupae of the genus Hyperechia (Diptera, Asilidae). Transactions of the Entomological Society of London, 75, 177-185.

Tsacas, L.E., Desmier de Chenon, R. \& Coutin, R, (1970) Observations sur le parasitisme larvairs d'Hyperechia bomboides (Dipt. Asilidae). Annales de la Société entomologique de France, 6, 493-572.

Weber, G.S. \& Lavigne, R. (2004) Notes on the behavior of Blepharotes coriarius (Wiedemann, 1830) (Diptera: Asilidae) with a description of the pupal case. Studia dipterologica, 11, 13-21.

Wilcox, J. (1935) Description of the male of Willistonina bilineata (Williston) together with a new form (Diptera-Asilidae). Pan-Pacific Entomologist, 11, 31-34.

Zinov'eva, L.A. (1959) Biology and ecology of robber flies (Diptera, Asilidae) in the Naryn Sands. Entomological Review, 38, 499-511. 